\title{
骨導補聴器の音響機械特性に基づく装用効果の推定
}

\section{一擬似難聴による検討 -}

\author{
松平登志正 ${ }^{1)}$ 鈴木 恵子 ${ }^{11}$, 原 由紀 ${ }^{11}$ \\ 佐野 肇 ${ }^{2}$ ，岡本 牧人 ${ }^{2)}$ \\ ${ }^{1)}$ 北里大学医療衛生学部 \\ ${ }^{2)}$ 北里大学耳鼻咽喉科
}

\begin{abstract}
要旨：骨導補聴器の音響機械特性と装用耳の聴力から補聴域値を推測する方法について述 べ，その妥当性について検討するために，聴力正常者の両外耳道に耳せんまたはイヤモー ルド作成用印象剤を注入した擬似難聴11例において，音場で 2 種類の骨導補聴器の補聴域 值を実測し推定値と比較した。両補聴器とも，気導補聴器より大きい推定誤差がみられた が，本法は骨導補聴器の仮選択時の調整には十分な精度を有すると考えられた。また，骨 導補聴器のフィッティングを容易にする上で, 骨導補聴器の性能の表示を, 現在の音圧レ ベル/カのレベル表示から聴力レベル表示に変えること, 補聴器メーカーがこの資料を提 供することが必要であることを述べた。
\end{abstract}

$$
\text { ーキーワードー }
$$

骨導補聴器，補聴域值，音響機械感度レベル，メカニカルカプラ，擬似難聴

\section{1.はじめに}

先天性外耳道閉鎖など通常の気導補聴器が使用で きない一部の伝音難聴症例には，増幅した音声信号 を機械的振動として出力する骨導補聴器が用いられ ている。この際，骨導補聴器の音響機械特性に基づ き装用効果を推定することは，気導補聴器の場合と 同様に必要であり，乳幼児など装用効果の実測が困 難な場合の補聴器フイッティングには特に重要であ るが，その方法は十分確立されていない。

この理由の一つに, 骨導補聴器の特性と補聴効果 の関係が分かりにくいことがあげられる。骨導補聴 器の特性は，一定の入力音圧を加えたときに，メカ ニカルカプラ（人工マストイド）に压定した骨導受 話器が発生する力のレベルとして表示される ${ }^{1)}$ 。し かし, 気導補聴器の出力音圧レベル表示とは異なり, この特性から直ちに補聴器の装用効果を定量的に知
ることは困難である。補聴器の周波数別の装用効果 を表す指標には実耳挿入利得とファンクショナルゲ イン（functional gain）があるが，前者は骨導補聴 器では実施できないので, 後者が唯一の指標と言え る。Carlssonと Hakansson ${ }^{2)}$ は骨導埋め込み形補 聴器の特性からファンクショナルゲイン $(\mathrm{FG}) を$ 推定する次の式を導いている。

$$
\mathrm{FG}=\mathrm{MAF}-\mathrm{RETFL}_{\mathrm{DBC}}+\mathrm{AMSL}_{\mathrm{SPL}, \mathrm{FL}}
$$$$
\text { +装用耳の気導骨導差 }
$$

ここで, MAF は音場の基準等価域值音圧レベル, RETFL $_{D B C}$ は埋め込み形骨導子による直接骨導音の 基準等価域值力のレベル, $\mathrm{AMSL}_{\mathrm{SPL}, \mathrm{FL}}$ は骨導埋め 込久形補聴器の音響機械感度レベル (acousto-mechanical sensitivity level), すなわち, 骨導補聴器 出力の力のレベルと入力音圧レベルの差を表してい る1)。この方法は, RETFLDBC を骨導受話器の基準 等価域值力のレベル（RETFL）とすれば通常の骨 
導補聴器にも同様に適用できるが，直感的に理解し にくく，フィッティングソフトを用いて自動化を考 えない限り臨床での使用は困難と思われる。またこ の推定方法の妥当性も検証されていない。

本研究においては, 難聴者の聴力と骨導補聴器の 特性から骨導補聴器のファンクショナルゲインと補 聴域值を推定する [1]式とほほ等価な式を，直感的 に理解しやすい聴力レベル表示を用いて導き，その 妥当性を検証するために，擬似難聴例を対象に骨導 補聴器の補聴域値の推定を行い，実測値と比較して その精度について検討した。

\section{2. 骨導補聴器の装用効果の推定}

補聴器のファンクショナルゲインは，音場におけ る裸耳の聴覚域値レベル（X）と補聴時の聴覚域值 レベル（ $\mathrm{X}_{\mathrm{aided}}$ ，以後補聴域值と略称）の差で定義さ れる。これは線形増幅方式の補聴器の場合には，あ る特定レベルの入力音を音場で聞いたときの，補聴 器装用の有無での感覚レベルの差に等しい。いま, 骨導補聴器装用耳の骨導の聴覚域值レベルを $\mathrm{x}_{\mathrm{b}} \mathrm{dB}$ ，聴力レベル $\mathrm{L} \mathrm{dB}$ の音場入力音に対する骨 導受話器の出力音の聴力レベルを $\mathrm{L}_{\mathrm{b}} \mathrm{dB}$ とすると, 裸耳で聴取時の入力音の感覚レベルは $(\mathrm{L}-\mathrm{X}) \mathrm{dB}$, 補聴器装用時の骨導受話器からの骨導音の感覚レべ ルは $\left(\mathrm{L}_{\mathrm{b}}-\mathrm{x}_{\mathrm{b}}\right) \mathrm{dB}$ に等しい（図 1$)$ 。したがって， この骨導補聴器のファンクショナルゲイン $(\mathrm{FG})$ は両者の差をとり変形して,

$$
\begin{aligned}
\mathrm{FG} & =\mathrm{X}-\mathrm{X}_{\text {aided }} \\
& =\left(\mathrm{L}_{\mathrm{b}}-\mathrm{x}_{\mathrm{b}}\right)-(\mathrm{L}-\mathrm{X}) \\
& =\left(\mathrm{X}-\mathrm{x}_{\mathrm{b}}\right)+\left(\mathrm{L}_{\mathrm{b}}-\mathrm{L}\right)
\end{aligned}
$$

で表される。さらに，音場入力音の聴力レベルが $\mathrm{L}$ $\mathrm{dB}$ の時の, 骨導補聴器装用時における補聴器のマ イクロホンへの入力音压を $\mathrm{L}_{\mathrm{m}} \mathrm{dBHL}$ として，上の 式は,

$$
\mathrm{FG}=\left(\mathrm{X}-\mathrm{x}_{\mathrm{b}}\right)+\left(\mathrm{L}_{\mathrm{b}}-\mathrm{L}_{\mathrm{m}}\right)+\left(\mathrm{L}_{\mathrm{m}}-\mathrm{L}\right)
$$

と変形できる。

この式の右辺の第 1 項 $\left(\mathrm{X}-\mathrm{x}_{\mathrm{b}}\right)$ は, $\mathrm{X}$ をイヤホ ンによる聴力検查で得られる良聴耳の気導域値に等 しいと仮定すると，良聴耳の気導域值と骨導補聴器 装用耳の骨導域値との差(気導骨導差)に相当する。 第 2 項 $\left(\mathrm{L}_{\mathrm{b}}-\mathrm{L}_{\mathrm{m}}\right)$ は，は，いわば骨導補聴器の「利 得」にあたる量で, 補聴器のマイクロホンへの気導
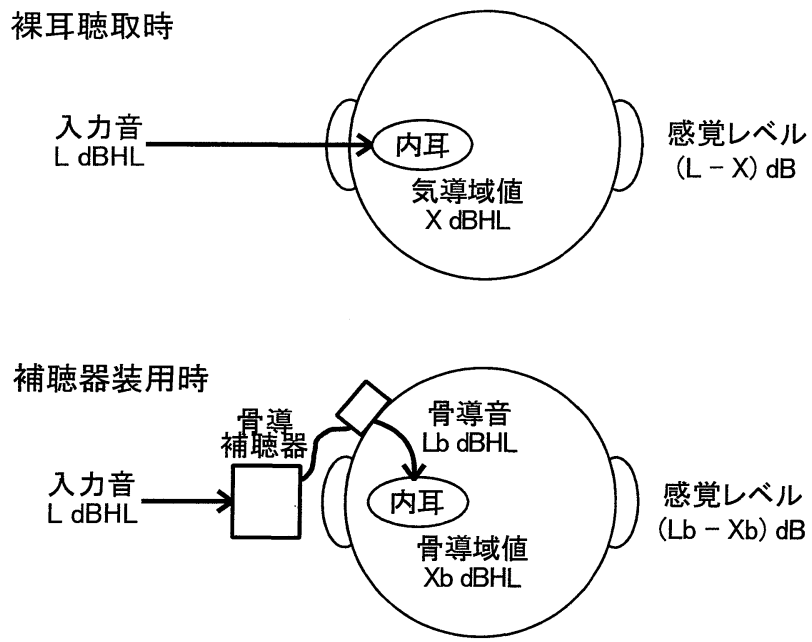

図 1 裸耳と骨導補聴器装用時における入力音の感覚レベル

入力と補聴器用受話器からの骨導出力の聴力レベル 表示でのレベル差を表わしている。これは［1]式に おける音響機械感度レベルを聴力レベル表示にした もので，聴力レベル表示の音響機械感度レベル（以 後 $\mathrm{AMSL}_{\mathrm{HL}}$ と略称）と呼ぶことにする。第 3 項（骨 導補聴器のマイク入力音圧と音場入力音圧の差) は 通常マイクロホン位置効果と呼ばれて補聴器の装用 形態により異なる。結局, 骨導補聴器のファンクシ ヨナルゲインは装用耳の気導骨導差（ただし気導域 值は良聴耳の值を用いる)，骨導補聴器の聴力レベ ル表示での音響機械感度レベル（AMSL $\left.\mathrm{HL}_{\mathrm{HL}}\right) ， お よ$ びマイクロホン位置効果の和に等しい，すなわち式 で表せば，

$\mathrm{FG}=$ 気導骨導差 $+\mathrm{AMSL}_{\mathrm{HL}}$

+マイクロホン位置効果

となる。この式で, AMSL AMSL $_{\mathrm{SPL}, \mathrm{FL}}$ に等しいので，[2]式は[1]式とマイ クロホン位置效果をのぞけば等価である。［2］式の 第 1 項は聴力検査結果，第 2 項は骨導補聴器の特性 測定から值が求められる。第 3 項は，箱型補聴器の 胸の位置での值については報告されている3 ${ }^{3}$ が，耳 掛け形骨導補聴器のマイク位置（頭部のヘッドバン ド上）での值については報告されていない。

気導補聴器のファンクショナルゲインは，補聴器 の音響利得によって決まり装用者の聴力には無関係 である。同じ補聴器を80dBHL の耳に装用しても60 dBHL の耳に装用しても同じファンクショナルゲ インが期待される。これに対して骨導補聴器では, 
[2]式によれば，伝音難聴があると気導骨導差の分 だけファンクショナルゲインは増加することにな る。[2]式は, 補聴器の $\mathrm{AMSL}_{\mathrm{HL}}$ が $0 \mathrm{~dB}$ の場合, マイクロホン位置効果を除けばファンクショナルゲ インは被験耳の気導骨導差に等しいことを意味して いる。気導補聴器は, 健聴者が聴取しても増幅音の 大きさから装用効果をある程度予想できるのに対し て, 骨導補聴器は, 健聴者が装用しても増幅効果が ほとんど感じられないのはそのためと考えられる。

また, 補聴域值 $\mathrm{X}_{\text {aided }}$ の推定值は [2]式の雨辺か ら Xを引いて得られる，

$\mathrm{X}_{\mathrm{aided}}=\mathrm{x}_{\mathrm{b}}-\mathrm{AMSL}_{\mathrm{HL}}$ - マイクロホン位置効果

により求めることができる。

\section{3. 対象と方法}

（1）耳掛け形補聴器 Rionet $\mathrm{HB}-13$, 箱形補聴器 Rionet HA-72P，および Danavox 107-2PPAGCI の出力を補聴器用骨導受話器 (Oticon BC462) に 接続して骨導補聴器とした。いずれも線形増幅方式 の補聴器である。以下ではこれらを，それぞれ耳掛 け形, 箱形 $\mathrm{A}$, 箱形 $\mathrm{B}$ と略称する。補聴器は規準 の状態とし, ボリウムは中間よりやや高出力の位置 とした。

入力音压 $60 \mathrm{dBSPL}$ と $90 \mathrm{dBSPL}$ で，骨導補聴器の 出力特性を人工マストイド B \& K 4930で測定した。 測定の配置の詳細は，ISO 118-91)によった。同様 に暗騒音下での $1 / 3$ オクターブ帯域ごとの骨導補 聴器の出力（内部雑音と略称する）を測定した。内 部雑音はボリウム最大の状態でも測定した。

（2）20２8歳（中央值22歳）の聴力正常者11名（男 3 ，女 8 ）を被験者とした。被験者のうち 5 名につ いては雨耳にイヤモールド作成用印象剤を注入， 6 名については両耳にスポンジ耳栓(イヤウィスパー) を挿入し擬似難聴とした。この状態で両耳の気導域 值と右の骨導域值をマスキングなしで250，500， 1000，2000，3000，4000Hzの 6 周波数において測 定した。

（3）防音室内で, 擬似難聴被験者をスピーカの前 方 $1 \mathrm{~m}$ の音場に着席させ, 被験者の耳の高さがス ピーカの高さ $(105 \mathrm{~cm})$ と等しくなるように椅子の 高さを調節した。裸耳聴取時㧍よび, 耳掛け形と箱
型 $\mathrm{A} の 2$ 種の骨導補聴器装着時に，スピーカから 中心周波数が250, 500, 1000, 2000, 3000, $4000 \mathrm{~Hz}$, 持続時間 1 秒の検査音を発生させて $5 \mathrm{~dB}$ ステップ で聴覚域值を求めた。検查音には純音聴力検査のマ スキング用の狭帯域雑音を用い，被験者を排除した ときの基準点（測定時における被験者の外耳道の入 口を結ぶ線分の中点 $)^{4)}$ の音圧を測定して音場入力 音圧の較正を行った。検査の際, 補聴器本体（マイ ク位置）は, 箱形は胸部に, 耳掛け形はヘッドバン ド上の骨導受話器と反対側端に接着固定し頭部に装 着した。

（4）（3）の耳掛け形骨導補聴器装用時の測定と同 じ配置で，20～30歳（中央值23歳）の16名（男 3, 女13）を被験者として, 音場入力音圧を50dBSPL とした時の, 頭部に装着した骨導補聴器のマイクロ ホンへの入力音圧を，1/4 インチマイクロホン（B \&K 4138）を補聴器のマイクロホンの真横におい て測定し, これから音場入力音圧を差し引いてマイ クロホンの位置効果をもとめた。

（5）骨導補聴器の特性の測定結果 $((1))$ と被験者 の聴力検査結果 $((2))$ から，[3]式により骨導補聴 器装用時の聴覚域值レベル（補聴域值）の推定值を もとめ, これを，（3）でもとめた実測值と比較し た。系統䛊差の有無の判断には, 両者の平均值の差 についての両側 $\mathrm{t}$ 検定（有意水準 $5 \%$ ）の結果を用 いた。

1 ) [ 3 ]式第 2 項の AMSL 器の入力音圧レベルや, 出力の力のレベルは, 基準 の音場音圧レベル5) や基準の力のレベル6) 引いて 聴力レベルに変換した。ただし基準の音場音圧レべ ルは両耳で聴取したときの值であるのに対して, 骨 導補聴器装用時は基本的には片耳装用なので, ANSI $^{7)}$ に倣いこれに $2 \mathrm{~dB}$ を加えた值を基準值とし て用いた。表 1 に箱型 $\mathrm{A}$ の今回使用した設定にお いて AMSL

2 ）第 3 項のマイクロホン位置効果は, 箱型補聴 器については報告されている值 ${ }^{3}$ を用いた。耳掛け 形補聴器については，（4）で測定した16名の平均 値を用いた。

3 ）計算の結果, 補聴域値の推定值が裸耳音場域 值を上回る場合は, 補聴域值の推定值は裸耳の域值 に等しいとした。 
表 1 聴カレベル表示の音響機械感度レベル（AMSLHL）の算出 箱型 $\mathrm{A}$ の今回使用した設定における計算例を示した。

\begin{tabular}{|c|c|c|c|c|c|c|c|c|}
\hline & 周波数 & $\mathrm{Hz}$ & 250 & 500 & 1000 & 2000 & 3000 & 4000 \\
\hline (1) & 音場入力音圧レベル & dBSPL & 60 & 60 & 60 & 60 & 60 & 60 \\
\hline (2) & 基準の音場音圧レベル & $\mathrm{dBSPL}$ & 13 & 6 & 4 & 0.5 & -4 & -4.5 \\
\hline (3) & $\begin{array}{c}\text { 入力音の聴カレベル } \\
\text { Lm (1)-(2)) }\end{array}$ & $\mathrm{dBHL}$ & 47 & 54 & 56 & 59.5 & 64 & 64.5 \\
\hline & $\begin{array}{l}\text { 骨導補聴器出力のカの } \\
\text { レベル測定値 (図 2) }\end{array}$ & $\mathrm{dBFL}$ & 68.1 & 84.4 & 85.2 & 80.6 & 76.2 & 77.3 \\
\hline (5) & 基準のカのレベル & $\mathrm{dBFL}$ & 67 & 58 & 42.5 & 31 & 30 & 35.5 \\
\hline \multirow[t]{2}{*}{ (6) } & $\begin{array}{c}\text { 出力音の聴カレベル } \\
\text { Lb (4)-(5)) }\end{array}$ & $\mathrm{dBHL}$ & 1.1 & 26.4 & 42.7 & 49.6 & 46.2 & 41.8 \\
\hline & $\mathrm{AMSL}_{\mathrm{HL}}($ (6)-(3)) & $\mathrm{dB}$ & -45.9 & -27.6 & -13.3 & -9.9 & -17.8 & -22.7 \\
\hline
\end{tabular}

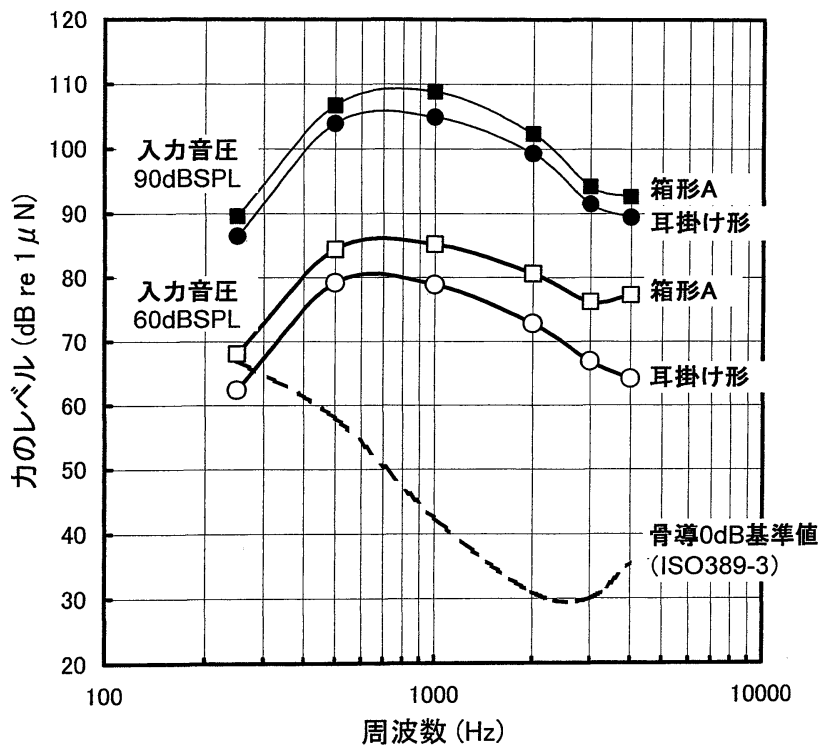

図 2 使用した骨導補聴器の出力の周波数特性

\section{4. 結果}

（1）入力音圧レベル $60 \mathrm{~dB}$ および $90 \mathrm{~dB}$ での耳掛け 形と箱型 $\mathrm{A}$ 骨導補聴器の音場検査で使用した設定 での出力の周波数特性を図 2 に示す。

（2）擬似難聴被験者の気導および骨導聴力域值を 図 3 に示す。同じ図に，音場検査で使用した設定で の箱形補聴器 $\mathrm{A}$ と耳掛け形補聴器の, 各周波数の $1 / 3$ オクターブ帯域での内部雑音を破線で示す。 また，2 台の箱形補聴器 $\mathrm{A} ， \mathrm{~B}$ でボリウムを最大に した場合の内部雑音の骨導出力を実線で示す。両補 聴器とも，中音域において，骨導域値を（帯域幅 1

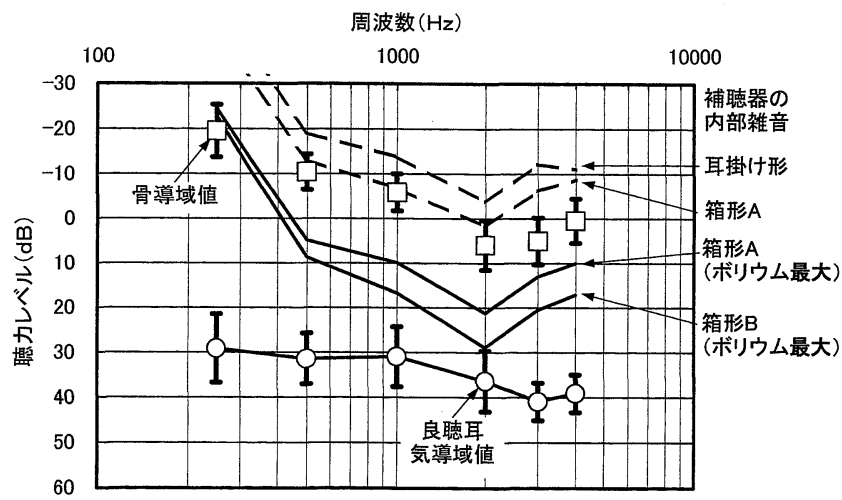

図 3 被験者の気導骨導聴力域値の平均と骨導補聴器の内部 雑音のレベル

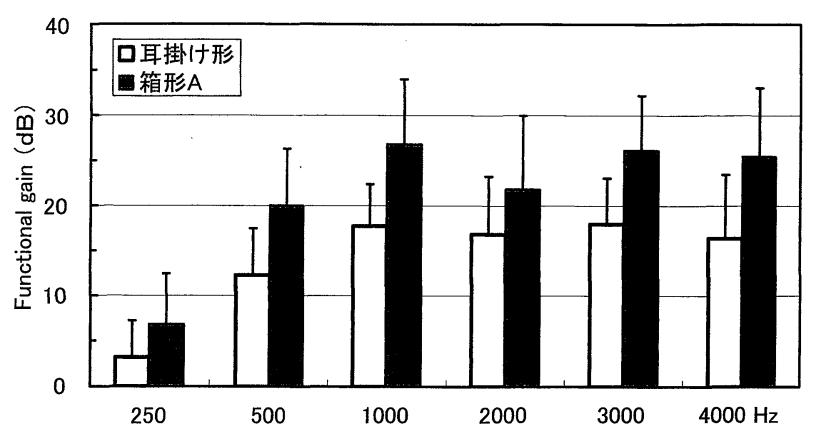

図 4 ファンクショナルゲインの実測值

/ 3 オクターブのバンドレベルで) $15 \sim 20 \mathrm{~dB}$ 上回 る内部雑音が認められた。

(3) 耳掛けおよび箱形 $\mathrm{A}$ 補聴器のファンクショナ ルゲインの実測值を図 4 に示す。

(4) 耳掛け骨導形補聴器のマイクロホン位置効果 
表 2 耳掛け骨導形と箱型補聴器のマイクロホン位置効果

(箱形補聴器の值は Kuhn と Guernsey ${ }^{3)}$ による)

\begin{tabular}{|c|c|c|c|c|c|c|c|}
\hline \multicolumn{2}{|c|}{ 周波数 $(\mathrm{Hz})$} & 250 & 500 & 1000 & 2000 & 3000 & 4000 \\
\hline \multirow{2}{*}{$\begin{array}{c}\text { 耳掛け骨導形 } \\
\text { (頭部) }\end{array}$} & 平均値 (dB) & 0.5 & -0.1 & 1.1 & 2.1 & 2.1 & 2.3 \\
\hline & 標準偏差 (dB) & 1.1 & 1.2 & 1.5 & 0.6 & 1.2 & 1.2 \\
\hline 箱形 (胸部) $\left.{ }^{3}\right)$ & 平均值 $(\mathrm{dB})$ & 3 & 5 & 3 & 2 & 1 & 0 \\
\hline
\end{tabular}

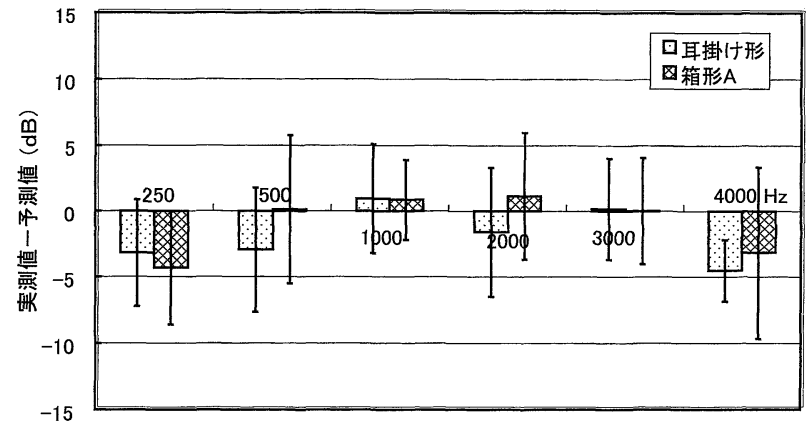

図 5 補聴域值推定の誤差

の測定結果およびKuhn と Guernseyによる箱型 補聴器のマイクロホン位置効果 ${ }^{3)}$ 表 2 に示す。

（5）補聴域値の実測值と推定值の差（実測值-推定 值，以後，符号付誤差と略称）の平均值と標準偏差 を，耳掛け形および箱形 $\mathrm{A}$ 骨導補聴器について図 5 に示す。 $250 \mathrm{~Hz}$ と $4000 \mathrm{~Hz}$ では両補聴器とも推定 值に比べ実測值が有意に小さい值が得られた（耳掛 け形 $4000 \mathrm{~Hz}$ で $\mathrm{p}<0.01$ ，他の 3 条件では $\mathrm{p}<0.05)$ が，その他の条件では，両者の差の平均值は $3 \mathrm{~dB}$ 未満で，実測值と予測值の平均值に有意差は認めら れなかった。推定の偶発䛊差の指標である，符号付 誤差の標準偏差（図 5 のエラーバーで表示）は，2.3 $\mathrm{dB} \sim 6.5 \mathrm{~dB}$ と条件により異なった值をとり，中央 值で $4.3 \mathrm{~dB}$ であった。また, 全被験者, 全条件の 符号付誤差は, 最大 $12.4 \mathrm{~dB}$ から最小 $-13.4 \mathrm{~dB}$ の範 囲に分布し，標準偏差は $4.8 \mathrm{~dB}$ であった。

\section{5. 考察}

（1）補聴域值推定の精度

Hawkins $ら^{8)}$ は，臨床検查より統制された条件 下で， $2 \mathrm{~cm}^{3}$ カプラ利得に基づく 6 周波数における 気導補聴器のファンクショナルゲインの推定を行っ た際の, 推定の符号付誤差の標準偏差を $1.8 \mathrm{~dB} \sim 4.0$ $\mathrm{dB}$ と報告している。これに比べて, 結果（5）に 述べた骨導補聴器の補聴域值の推定におけるばらつ
き（2.3dB〜6. $5 \mathrm{~dB} ）$ はやや大きいが，音場測定の 他に骨導域值測定のばらつきによる誤差が加わって いることを考慮すると特に大きいとはいえない。こ の程度の誤差であれば，骨導補聴器の装用効果の予 測に使用することは十分可能と考えられる。ただし， 今回の結果は聴力正常の成人を用いた結果であり, 例えば乳幼览の場合は，骨導域值の測定誤差の増加 を考慮する必要がある。また，同じく乳幼児や先天 性外耳道閉鎖例では，頭部の質量が小さいことや奇 形により乳突部の機械インピーダンスが正常成人の それと異なるため, 正常成人のインピーダンスを模 擬しているメカニカルカプラによる骨導受話器出力 の測定值が，実耳乳突部に発生する振動との間に不 一致が生じる可能性がある。したがって，これらの 症例において本法を適用する場合は, 誤差は今回得 られた值より大きくなる可能性が高く，その程度に ついては今後さらに検討が必要と考えられる。

今回の補聴域值予測では, $250 \mathrm{~Hz}$ と $4000 \mathrm{~Hz}$ を除 き推定值と実測値に有意差は認められず，概ね偶発 的な要因によるものであり, 推定式の不備などの理 論的要因による誤差 (系統誤差) は $4000 \mathrm{~Hz}$ を除け ば少ないと考えられる。 $250 \mathrm{~Hz}$ において実測值の 平均值が推定値の平均より有意に小さい值となった のは次の理由によると考えられる。今回の補聴器の 設定では，この周波数の $\mathrm{AMSL}_{\mathrm{HL}}$ が小さく(図 1, 図 6-A）補聴域值の予測值が裸耳域值を上回る場 合がかなりあった。この場合，補聴域值の推定值は 3-（5）-3）で述べたように全て裸耳の域值に等 しいとしたが, 実際の補聴器出力の域值が裸耳域值 より高い場合は補聴域值の実測値も裸耳域值に等し くなり誤差は 0 になるのに対して，実際の補聴器出 力の域值が裸耳域值より低い場合は裸耳域值より補 聴域值の実測值が低くなることがあり，符号付誤差 は 0 または負の值にしかならなかったためと考えら れる。 
（2）補聴域值推定に影響を与える要因

1 ) 内部雑音の影響

周波数 $\mathrm{f}$ の検查音のマスキングに寄与する内部雑 音の成分は中心周波数を $\mathrm{f}$ とする臨界帯域幅内の雑 音成分である。臨界帯域幅内の雑音の強さとこの雑 音下での域值に相当する検査音の強さの関係は，前 者が後者より約 $4 \mathrm{~dB}$ 大きいことが知られてい る ${ }^{9)}$ 。したがって，骨導補聴器の臨界带域幅内の骨 導内部雑音出力を $\mathrm{L}_{\mathrm{bn}}(\mathrm{dBHL})$ とすると，この雑 音下でのその中心周波数 $\mathrm{f}$ の検査音の域值は $\mathrm{L}_{\mathrm{bn}}-$ 4 （dBHL）に等しい。したがって，この周波数に おける装用耳の骨導域値 $\mathrm{x}_{\mathrm{b}}$ が $\mathrm{L}_{\mathrm{bn}}-4$ より大きい場 合は，内部雑音は骨導域值に影響しないので，骨導 補聴器の補聴域值 $\mathrm{X}_{\text {aided }}$ は 2 。の $[3]$ 式によりもと とめられる。これに対して， $\mathrm{x}_{\mathrm{b}}<\mathrm{L}_{\mathrm{bn}}-4$ の場合は, 骨導域值は $\mathrm{L}_{\mathrm{bn}}-4$ まで上昇するので，補聴域值は，

$\mathrm{X}_{\text {aided }}=\mathrm{L}_{\mathrm{bn}}-4-\mathrm{AMSL}$-マイク位置効果

となる。ここで，右辺の（L $\mathrm{L}_{\mathrm{bn}}-\mathrm{AMSL} ）$ は補聴器 の等価入力雑音レベルに等しい。 $\mathrm{L}_{\mathrm{bn}}$ の近似値を得 るために結果（2）では雑音のレベルを $1 / 3$ オク ターブの帯域幅で測定したが，この帯域幅は $500 \mathrm{~Hz}$ では臨界帯域幅に等しい。それ以下の周波数では臨 界帯域幅より狭いので $\mathrm{L}_{\mathrm{bn}}$ は測定值より大きくな り，500Hz 以上の周波数では臨界帯域幅より広い ので $\mathrm{L}_{\mathrm{bn}}$ は測定值より小さくなるが差は $2 \mathrm{~dB}$ 以内 である。

内部雑音の効果を図 3 の結果についてみると, 今 回音場検查に用いた補聴器の設定では，骨導補聴器 の内部雑音は骨導域值より小さい場合が多くその影 響は余り問題にならなかったが，骨導域値より $4 \mathrm{~dB}$ 以上内部雑音のレベル $\left(\mathrm{L}_{\mathrm{bn}}\right)$ が上回るとマスキン グが起こることになる。特に，ボリウムを最大に近 い值としてこれらの骨導補聴器を使用する場合に は，伝音難聴では特に中音域で骨導域値をかなり上 回る骨導雑音が聴取され, 補聴域值も上昇すること になる。その場合の補聴域值の推定值は [4]式によ り得られる。

図 3 の内部雑音の測定結果は $1 / 3$ オクターブ帯 域の雑音のレベルを示しているが，この帯域幅は， $1000 \mathrm{~Hz}$ 以上では臨界帯域幅より広いため， L これより 1 〜 $2 \mathrm{~dB}$ 小さい值となる。
2 ）マイクロホン位置効果

耳掛け骨導形補聴器は, 装用時にマイクロホンは 耳介より前上方の頭部に位置することになる。箱型 補聴器では最大 $5 \mathrm{~dB}$ のマイクロホン位置効果が低 音域にみられるのに対して，耳掛け骨導形補聴器の マイクロホン位置効果は, 高音域で平均 $2 \mathrm{~dB}$ 強の 值となった（表 2 )。どちらの形についても補聴域 值推定の誤差のばらつきを考えると，小さい值とい えるので，大まかな推定を行う場合には，この項は 省略してもよいかもしれない。

3 ）骨導基準値の受話器間差

骨導補聴器の出力の聴力レベル值は，メカニカル カプラで測定された力のレベルから聴力正常耳の聴 覚間值に相当する力のレベル（基準等価域值の力の レベル）を差し引いて求められる。この基準等価間 值の力のレベルは骨導補聴器用受話器で測定された 值ではなく，聴力検査用骨導受話器で得られた基準 值)に等しいと仮定してこれを用いている。この二 つの受話器は，質量，圧定面の形状（前者は丸みを もった台形状の曲面，後者は円形の平面)，ヘッド バンドの圧定力（前者は公称 $2.5 \mathrm{~N}$ ，後者は公称 4.5 $\mathrm{N})^{1,10)}$ が異なることを考えると，両受話器の基準值 が異なる可能性は十分考えられ，両者の差は誤差の 一因となる。今回使用したのと同じ型式の聴力検査 用骨導受話器と補聴器用骨導受話器を用いて, 同じ 被験者の骨導聴覚間値をもとめ，これに相当する力 のレベル(等価域值の力のレベル)を比較した結果, 両者が異なっていることが報告されている ${ }^{11)}$ 。今回， 予備実験として，同様の測定を行った結果，やはり， 周波数によっては有意差を認めたものの，以前の報 告と差の值がかなり異なっていたため，今回の補聴 域値の推定においてはこの差を考慮しなかった。推 定の精度を改善する上で，今後この差の值を決定す ることが必要である。

（3）音響機械特性にもとづく骨導補聴器のフィッ ティング

気導補聴器のフィッティングでは，音響特性に基 づき補聴器を選択調整する方法が確立している。難 聴者の聴力をもとに, 補聴器の挿入利得（ファンク ショナルゲイン）の目標值を設定して，これを達成 するように補聴器を選択し音響特性の仮設定が行わ れている。この際補聴器の音響特性は，補聴器特性 

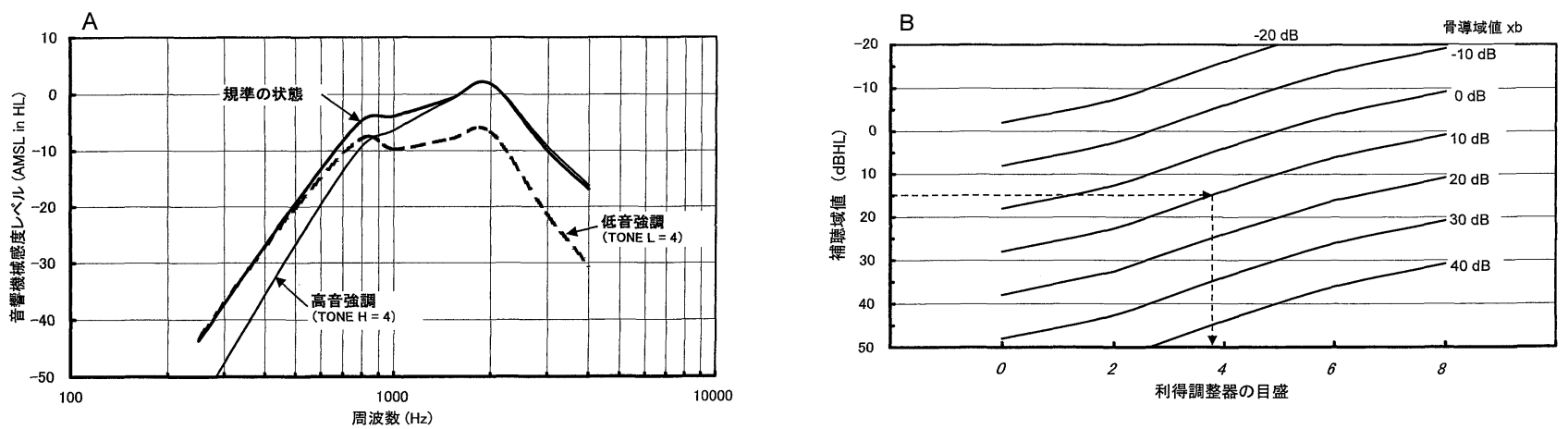

図 6 骨導補聴器の特性の表示例

$\mathrm{A}$ ：音響機械感度レベル（聴力レベル表示）の周波数レスポンスと音質調整器の効果（利得調整器の目盛は 4 , マイクロホン位 置効果も算入した值)。グラフの值に装用者の気導骨導差を加えればファンクショナルゲインの推定值が得られる（本文 $[2]$ 式 を参照)。例えば，グラフから，基準の状態で $500 \mathrm{~Hz}$ の AMSL は約-20dB なので，この状態で気導骨導差が35dB の耳に装用す るとファンクショナルゲインは $15 \mathrm{~dB}$ と推定される。 B : 骨導域値別にみた利得調整器の目盛と補聴域值の推定值 $(1000 \mathrm{~Hz}$ にお ける値，マイクロホン位置効果算入済み，内部雑音の影響は考慮されていない)。例えば，グラフから，骨導域值が10dBHLの 耳にこの補聴器を装用した場合の補聴域值を $15 \mathrm{~dB}$ にしたいときは利得調整器のつまみを 4 弱にすればよいことが分かる。

測定装置で測定して知ることができる。これが無い 場合でも, 補聴器の音響特性はメーカーのカタログ (技術資料) に表示されているし，デジタル補聴器 ではフィッティングソフト上で概要を知ることがで きる。これに対して，骨導補聴器のフィッティング においては，機種の選択・調整を行う上で必要な 個々の補聴器の出力特性を知ることが臨床現場にお いては困難なのが現状である。まず，骨導補聴器の 特性を測定するにはメカニカルカプラが必要である が，イヤホン用の $2 \mathrm{~cm}^{3}$ カプラに比べて高価であり， 使用頻度も低いので普及していない。また，冒頭で 述べたように，国際規格で1) 骨導補聴器のカタログ への記載が規定されている特性はフィッティングに

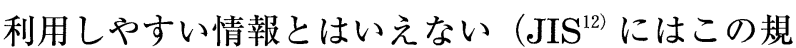
定も無い)。現実には，骨導補聴器として製作・市 販されている補聴器の機種はわずかで, 高出力の箱 形または耳掛け形補聴器の出力に骨導補聴器用骨導 受話器を接続して用いられることが多く，メーカー から補聴器の特性の情報を得ることはできない。

この点を解決する上で，以下のような方法が考え られる。現在わが国では，骨導補聴器用の骨導受話 器として使用されているのは実質的に 1 社の製品 （Oticon BC462）のみである。そこで，補聴器の各 メーカーが, 自社で骨導補聴器として使用しうる高 出力補聴器のカタログに，この骨導受話器を接続し たときの特性を表示すれば，これを元にフィッティ
ングが可能になる。少なくとも，問い合わせればこ の特性を提供できるように準備しておくことをメー カーに望みたい。

(4) 骨導補聴器の特性の表示法について

2.で述べたように，IEC 118-9には，骨導補聴 器の出力の $\mathrm{AMSL}_{\mathrm{SPL}, \mathrm{FL}}$ による表示が規定されてい るが ${ }^{1}$ ，この值は力のレベルと音圧レベルによる表 示であるため, 補聴器の性能の表示としては適当で あってもフィッティング上の意義は解りにくい。こ れに対して，この AMSL から基準の力のレベルを 引き，基準の音場音圧レベル5) を加えて聴力レベル 表示にした $\mathrm{AMSL}_{\mathrm{HL}}$ は，式[2]から明らかなよう に，(マイクロホン位置効果をのぞけば）この補聴 器を感音難聴耳が装用した時のファンクショナルゲ インの推定值に等しく，これに気導骨導差を加えれ ば伝音難聴耳のファンクショナルゲインが推定でき るので，この形で特性が表示されていればフィッテ イングが容易になると考えられる。今回使用した箱 形骨導補聴器 $\mathrm{A}$ につき特性の表示例を図 6 に示す。

\section{6. 結語}

骨導補聴器においても, 音響機械特性から装用効 果を推定すること可能であり，目標とする装用効果 （装用域值またはファンクショナルゲイン）が得ら れるように補聴器を処方・調整することが望まし い。そのためには, 補聴器のメーカーが自社の補聴 
器について骨導受話器を接続した時の聴力レベル表 示の音響機械感度レベルを提供することが望まし い。

\section{謝辞}

本研究の一部は，科学研究費補助金基盤研究 (C) (2)15500382の補助による。

本論文の要旨は, 第50回日本聴覚医学会学術講演 会においてロ演した。

\section{Estimation of the Aided Threshold for a}

Bone Conduction Hearing Aid from Its Acousto-mechanical Characteristics -A Study Using Simulated Hearing Loss-

\author{
Toshimasa Matsuhira ${ }^{1)}$, Keiko Suzuki ${ }^{1}$, Yuki \\ Hara $^{1)}$, Hajime Sano ${ }^{2)}$, Makito Okamoto ${ }^{2)}$ \\ ${ }^{1)}$ School of Allied Health Science, Kitasato \\ University \\ ${ }^{2)}$ Department of Otolaryngology, Kitasato \\ University
}

For some patients with conductive hearing loss, a bone conduction hearing aid (BCHA) remains the only choice for amplification. However, quantitative estimation of hearing improvement based on the physical characteristics of BCHAs has not yet been established. In this study, we examined the validity of a formula for estimating the aided threshold of a BCHA from pure-tone bone conduction thresholds of the wearer and the output characteristics of the BCHA. In 11 normal-hearing adults in whom the ear canals of both sides were plugged to simulate hearing loss, the aided thresholds for two types of BCHA were measured in sound fields and compared with the threshold estimated using the above formula. There were no significant differences between the two thresholds, except at $4000 \mathrm{~Hz}$, where the amplification was overestimated. The estimation errors in SD were from 2.3 to $6.5 \mathrm{~dB}$ depending on the frequency and type of hearing aid. Although some- what greater than that reported for the airconduction hearing aid, this variability is sufficiently small to indicate the possibility that the aided threshold or functional gain for BCHAs can be estimated and their characteristics prescribed. To make such a prescription clinically possible, it is necessary for hearing aid manufacturers to provide the data of the acousto-mechanical characteristics of their BCHAs in hearing level representation.

\section{参考文献}

1 ) IEC $118-9:$ Hearing Aids, Part $9:$ Methods of measurement of hearing aids with bone vibrator output. 1985

2 ) Carlsson, PU and Hakansson, BEV: The bone-anchored hearing aid : reference quantities and functional gain. Ear and Hearing 18 (1) : 34-41, 1997

3 ) Kuhn GF, Guernsey KM : Sound pressure distribution about the human head and torso. $J$ Acoust Soc Amer 73(1) : 95-105, 1983

4 ) ISO 8253-2: Audiomeric test methods, Part 2 : Sound field audiometry with pure tone and narrow-band test signals. 1992

5 ) ISO $389-7:$ Reference zero for the calibration of audiometric equipment, Part $7:$ Reference threshold of hearing under free-field and diffuse-field listening conditions. 1996

6 ) ISO $389-3:$ Reference zero for the calibration of audiometric equipment, Part $3:$ Reference equivalent threshold force levels for pure tones and bone vibrators. 1994

7 ) ANSI S3. $6:$ Specification for audiometers. 1996

8 ) Hawkins DB, Montgomery AA, Prosek RA, et al : Examination of two issues concerning functional gain measurements. J Speech Hear Dis $\mathbf{5 2}: 56-63,1987$

9 ) Scharf B : Critical bands. In Tobias JB(ed), Foundation of Modern Auditory Theory, Vol. 1, Academic Press, New York, 1970, pp159-202 
10）JIS T1201-1：オージオメータ-第 1 部：純音オ ージオメーター。2000

11）松平登志正，山下公一，高島雅之·他：骨導補 聴器のファンクショナルゲインの予測と受話器の $0 \mathrm{~dB}$ 基準值。Audiology Japan 37：369-370, 1994

12) JIS C5512：補聴器。2000

（原稿受付 平成18.7.13）
別冊請求先 $\overline{7} 228-8555$ 神奈川県相模原市北里1$15-1$

北里大学医療衛生学部 松平登志正

\section{Reprint request :}

Toshimasa Matsuhira

School of Allied Health Science, Kitasato University

1-15-1 Kitasato, Sagamihara, Kanagawa, 2288555 Japan 